\title{
Editorial: Black and White, Red and Blue
}

A young Greek student who arrived in Cambridge thirty years ago to read for the Classical Tripos went to Bowes and Bowes to equip himself with the necessary works of reference. Besides his Liddell and Scott and his Lewis and Short he came away with a copy of $A$ Guide to the Classics by Michael Oakeshott and G. T. Griffith, Fellows of Gonville and Caius College, not noticing that it was subtitled 'How to Pick the Derby Winner'. Even when an author or editor is trying to avoid ambiguity there may still be questions of interpretation. The April 1926 issue of the Fournal of Philosophical Studies printed three articles under the collective title 'The Problem of Colour in Relation to the Idea of Equality'. They were the texts of papers read at a meeting of the newly founded British Institute of Philosophical Studies at the Royal Society of Arts on I6 February 1926. The title might suggest a symposium on problems discussed earlier by Goethe or later by Wittgenstein, or perhaps some investigation into the distinction between $a$ priori and empirical concepts. The uncertainties of readers cannot have been long-lived. The symposiasts were Sir Frederick Lugard, KCMG, CB, DSO, Morris Ginsberg, MA, D.Litt. and the Hon. H. A. Wyndham. The same volume contained 'The Primitive and the Civilized Mind' by N. Lossky and the 1927 volume added Professor R. F. A. Hoernle's 'Prolegomena to the Study of the Black Man's Mind'.

The issues discussed in 1926 and 1927 have not ceased to be topical. $\mathrm{Mr}$ Wyndham spoke of the growing idea that 'although contact between select individuals of different race and colour should be encouraged, contact between them in the mass should be avoided, for nothing creates more colour prejudice than competition for daily bread or political control'. He reported a divergence of view in South Africa between the Cape and the other provinces in which the Cape 'has always been the protagonist of the principle of equal rights for all civilized men, and therefore has based its franchise on a low property qualification and a simple education test, with no colour bar at all'. The view of the northern provinces is quoted from a speech given by General Smuts in London in 1918:

Instead of mixing up black and white as we have done, confusing everything and not lifting up the blacks but degrading the whites, we are now trying to keep them apart as much as possible in our institutions, in landownership, in forms of government, and in many ways. We are trying to keep them apart and thus lay down an outline of policy 
which may take a hundred years to work out, but which, in the end, may be the solution of our native problem.

The British Institute is now the Royal Institute and the fournal of Philosophical Studies long ago changed its name to Philosophy. But the Institute maintains its active concern with problems of moral and political practice. The Lecture Programme for $1983-84$, printed on p. 427 of this issue, is on 'Philosophy and Practice'. There is no lecture explicitly on questions of race, but we learn from p. 428 that the Newcastle Branch makes good the deficiency with 'Racism and Xenophobia' by Dr Martin Hughes. The London series ranges from Public Worship to Juries, Prisons and Punishment, from Madness to Adoption, from Sex to the Right to Strike.

The same page shows that we have new allies in the pursuit of our objectives. The Society for Applied Philosophy, its inaugural announcement tells us,

has been established to provide a focus for philosophical research with a direct bearing on areas of practical concern which are capable of being illuminated by the critical, analytic approach characteristic of philosophy, and by direct consideration of questions of value. These areas include law, politics, economics, science-policy, medicine and education but are not confined to these. The Society's aim is to foster and promote philosophical work which is intended to make a constructive contribution to problems in these areas.

The means will include lectures, seminars and conferences, and the publication of a Fournal of Applied Philosophy. Enquiries should be addressed to Brenda Cohen, Philosophy Department, Surrey University, Guildford $\mathrm{GU}_{2}{ }_{5} \mathrm{XH}$.

At the first annual meeting of the British Institute, Dean Inge, proposing a vote of thanks to the President, Lord Balfour, remarked that British philosophy was unprofessorial without being unprofessional: 'The large majority of our philosophers are not merely professors of metaphysics, they are nearly always something else, and often something else important as well. It has happened several times that they have been men versed in affairs and prominent in politics, like our President and Lord Haldane. They have indeed exemplified almost every hue of the political spectrumfrom the conservative blue of our President to the relativist pink of Lord Haldane and the uncompromising red of the Master of Balliol.'

Perhaps the same range of colours will be represented in the ranks of the new Society. We hope that all the hues, and both Societies, will be accorded separate but equal development. 